\title{
Vertical Transmission of Severe Acute Respiratory Syndrome Coronavirus 2: A Systematic Review
}

\author{
Ziyi Yang, MBBS ${ }^{1,2}$ Yi Liu, $\mathrm{MD}^{2}$ \\ ${ }^{1}$ The First Clinical College of Chongqing Medical University, \\ Chongqing, China \\ 2 Department of Obstetrics, Chengdu Jinjiang Maternity and Child \\ Health Hospital, Chengdu, China \\ Am J Perinatol 2020;37:1055-1060.
}

\begin{abstract}
Address for correspondence Yi Liu, MD, Department of Obstetrics, Chengdu Jinjiang Maternity and Child Health Hospital, 3 Sanguantang Street, Chengdu 610011, China (e-mail: liuyicdjj@gmail.com).
\end{abstract}

\begin{abstract}
Keywords

- severe acute respiratory syndrome coronavirus 2

- coronavirus disease 2019

- vertical transmission

- neonate

- systematic review

Objective The aim of this study is to summarize currently available evidence on vertical transmission of severe acute respiratory syndrome coronavirus 2 (SARS-CoV-2). Study Design A systematic review was conducted following the guidelines of the Preferred Reporting Items for Systematic Reviews and Meta-analysis Statement.

Results A total of 22 studies comprising 83 neonates born to mothers diagnosed with coronavirus disease 2019 were included in the present systematic review. Among these neonates, three were confirmed with SARS-CoV-2 infection at 16, 36, and 72 hours after birth, respectively, by nasopharyngeal swab real-time polymerase chain reaction (RT-PCR) tests; another six had elevated virus-specific antibody levels in serum samples collected after birth, but negative RT-PCR test results. However, without positive RTPCR tests of amniotic fluid, placenta, or cord blood, there is a lack of virologic evidence for intrauterine vertical transmission.

Conclusion There is currently no direct evidence to support intrauterine vertical transmission of SARS-CoV-2. Additional RT-PCR tests on amniotic fluid, placenta, and cord blood are needed to ascertain the possibility of intrauterine vertical transmission. For pregnant women infected during their first and second trimesters, further studies focusing on long-term outcomes are needed.
\end{abstract}

\section{Key Points}

- We review neonates of mothers diagnosed with coronavirus disease 2019 detected by RT-PCR.

- No direct virologic evidence of vertical transmission has been reported.

- No evidence that cesarean delivery is safer than vaginal delivery.

- More RT-PCR tests on amniotic fluid, placenta, and cord blood are recommended.

Coronavirus disease 2019 (COVID-19) is an emerging disease caused by severe acute respiratory syndrome coronavirus 2 (SARS-CoV-2) with a rapid increase in cases and deaths since it was first reported in Wuhan, Hubei Province, China., ${ }^{1,2}$ Pneumonia caused by SARS-CoV-2 is highly infectious and the World Health Organization declared a global pandemic on March 11, 2020. As of April 22, 2020, over 2,500,000 confirmed cases and 173,000 confirmed deaths have been reported globally. The evidence base for person-to-person transmission of SARS-CoV-2 is solid, and there has been a rapid increase in knowledge of the genetic, virologic, epidemiologic, and clinical aspects of this disease. ${ }^{3}$ Due to the physiological changes during pregnancy, expectant mothers may face greater risk of infection. ${ }^{4}$ However, existing data about its vertical transmission from an expectant mother to her fetus and neonate remain inconclusive. Answers to this received

April 24, 2020

accepted after revision

April 26, 2020

published online

May 13, 2020
Copyright $\odot 2020$ by Thieme Medical Publishers, Inc., 333 Seventh Avenue, New York, NY 10001, USA. Tel: +1(212) 760-0888.
DOI https://doi.org/ 10.1055/s-0040-1712161. ISSN 0735-1631. 
question are essential for formulating the principles of obstetric care for pregnant women with SARS-CoV-2 infection. Therefore, we conducted this systematic review to summarize the currently available evidence on vertical transmission of SARS-CoV-2.

\section{Materials and Methods}

We conducted a systematic review following the guidelines of the Preferred Reporting Items for Systematic Reviews and Metaanalysis Statement. The protocol of this systematic review is registered with Open Science Framework (DOI: 10.17605/OSF.IO/Y5SR6). A comprehensive literature search of the following databases was performed on April 20, 2020: PubMed, the China National Knowledge Infrastructure, CBMdisc, and Wanfang Data. Two authors independently and systematically searched these databases using the following MeSH terms: "pregnancy," "infant, newborn," "COVID-19," and "severe acute respiratory syndrome coronavirus 2." We also performed a manual search in Google Scholar and the websites of key journals in the related field. Reference lists of included studies were also hand searched for potential eligible studies. Studies were considered for inclusion if they were observational studies or case report/series reporting neonates of mothers diagnosed with COVID-19 by real-time polymerase chain reaction (RT-PCR). There was no restriction on language, but the date of publication was limited to the period from January 1, 2020 to April 20, 2020.

The Newcastle-Ottawa scale was used to assess the quality (risk of bias) of cohort and case-control studies. For case report/series, a modified tool for quality appraisal was used; details can be found in the protocol. All methodological procedures were conducted by two authors independently. Disagreements were resolved by discussion with an expert in the related field.

\section{Results}

In the initial search, 197 unique records were identified and the full text of 25 was assessed. In total, 22 studies comprising 83 neonates were included in this review. The flow diagram of the study selection process and the characteristics of included studies are shown in - Fig. 1 and $=$ Table 1 , respectively. All 22 studies were rated as low quality. Among the 83 neonates, 9 had evidence of SARS-CoV-2 infection (positive RT-PCR results or elevated level of virus-specific antibodies in serum samples). Timelines illustrating the evolution of the results of RT-PCR and antibody tests are shown in -Fig. 2.

Alzamora et $\mathrm{al}^{5}$ reported a pregnant woman who developed respiratory failure and underwent a cesarean delivery at 33 weeks of gestation. Neonatal isolation was implemented immediately after birth, without any physical contact with the mother. A nasopharyngeal swab collected from the neonate at 16 hours after birth tested positive for SARS-CoV-2 by RT-PCR, although serum samples were negative for virus-specific immunoglobulin $\mathrm{G}$ ( $\operatorname{IgG}$ ) and immunoglobulin M (IgM) using automated chemiluminescence immunoassays. The RT-PCR test repeated 48 hours later for confirmation was also positive.

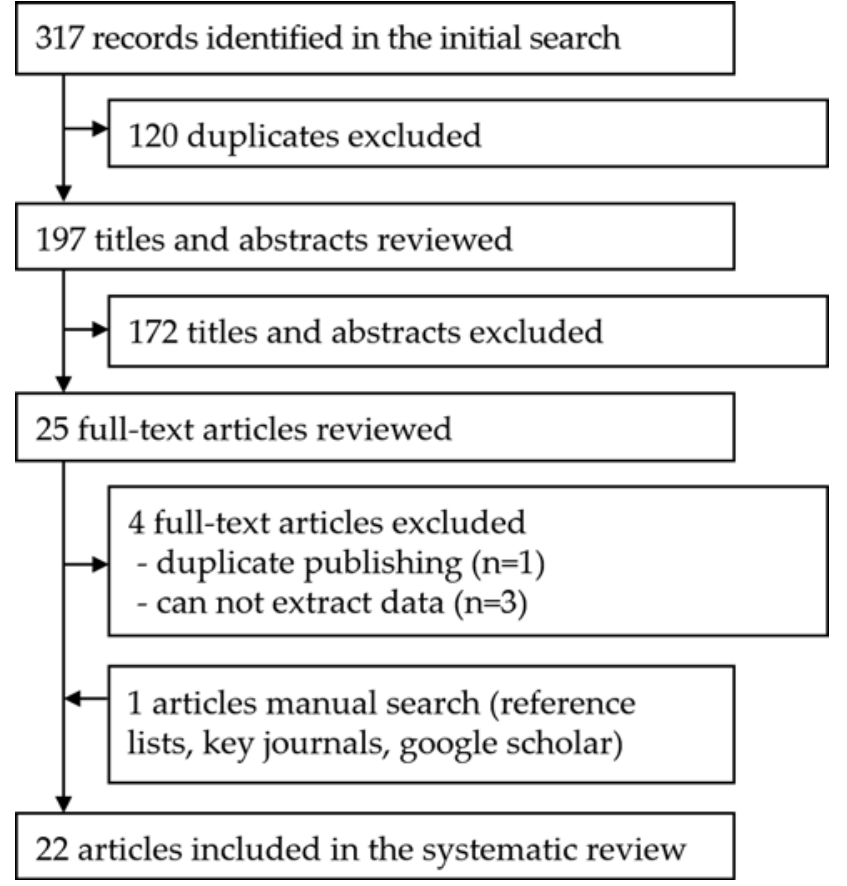

Fig. 1 Flow diagram of study selection process.

Similarly, Li et $\mathrm{al}^{6}$ and Yu et $\mathrm{al}^{7}$ also reported neonatal infection and the implementation of neonatal isolation measures immediately after birth. In these two cases, the mothers wore an N95 mask during delivery and the newborns were cared for under isolation in a separate pediatric room. RT-PCR test results at 36 hours and 3 days after birth were positive. In these three cases, no amniotic fluid, placenta, or cord blood were collected for RT-PCR tests.

Zeng et $\mathrm{al}^{8}$ and Dong et $\mathrm{al}^{9}$ both reported positive detection of virus-specific antibodies in serum samples drawn from the neonates following birth, although serum and throat swab samples tested negative by RT-PCR. Three of seven infants had elevated IgG and IgM levels; another three had elevated IgG levels, while IgM levels were normal. The mothers' vaginal secretions and breastmilk also tested negative by RT-PCR.

\section{Discussion}

In terms of virus infection during pregnancy, obstetricians are most concerned about the possibility of vertical transmission from the mother to her fetus. Vertical transmission has been confirmed for many viruses and can lead to adverse perinatal outcomes including miscarriage, fetal growth restriction, preterm birth, and even stillbirth. ${ }^{10,11}$ The routes of vertical transmission include intrauterine transmission, transmission during delivery, breast milk transmission, and contact after delivery. ${ }^{12}$ Of these, intrauterine vertical transmission is the least likely to be controlled and managed, and is the most important route of mother-to-child transmission that affects the fetus and neonates. Based on the results of the present systematic review, there is currently no direct evidence to suggest that the development of COVID-19 pneumonia in 
Table 1 Characteristics of included studies

\begin{tabular}{|c|c|c|c|c|c|}
\hline Study (year) & Country & Delivery mode & $\begin{array}{l}\text { Number of } \\
\text { neonates } \\
\text { tested }\end{array}$ & $\begin{array}{l}\text { Samples (time of sample } \\
\text { collection) }\end{array}$ & $\begin{array}{l}\text { Sample } \\
\text { test } \\
\text { results }\end{array}$ \\
\hline
\end{tabular}

$\begin{array}{llll}\begin{array}{l}\text { Alzamora et } \mathrm{al}^{5} \\ (2020)\end{array} & \text { Peru } & \text { Cesarean delivery } & 1 \\ \begin{array}{l}\text { Chen et al } \\ \text { (2020) }\end{array} & \text { China } & \text { Cesarean delivery } & 6\end{array}$

$\begin{array}{llll}\begin{array}{l}\text { Chen et al } \\ (2020)\end{array} & \text { China } & \text { Cesarean delivery } & 1 \\ & & \\ & & \\ & & & \\ \begin{array}{l}\text { Chen et al } \\ (2020)\end{array} & \text { China } & \text { Cesarean delivery } & 3 \\ \begin{array}{l}\text { Dong et al } \\ \text { (2020) }\end{array} & \text { China } & \text { Cesarean delivery } & 1\end{array}$

$\begin{array}{llll}\begin{array}{l}\text { Chen et } \mathrm{al}^{18} \\ (2020)\end{array} & \text { China } & \text { Cesarean delivery } & 1 \\ & & \\ \begin{array}{l}\text { Chen et al } \\ (2020)\end{array} & \text { China } & \text { Cesarean delivery } & 3 \\ \begin{array}{l}\text { Dong et al } \\ (2020)\end{array} & \text { China } & \text { Cesarean delivery } & 1\end{array}$

Serum sample IgG, IgM (at birth); neonatal nasopharyngeal swab (16 hours after delivery and repeated 48 hours later)

(2020)

Amniotic fluid (at the time of delivery); cord blood (immediately after delivery); neonatal throat swab (immediately after delivery); breastmilk (after first lactation)

Amniotic fluid (at the time of delivery); cord blood (immediately after delivery); placenta (immediately after delivery); breastmilk (day 1-5 postpartum); neonatal throat swab (day 1-7 after birth); stool (day 1-7 after birth)

Placenta (immediately after delivery); neonatal throat swab (specific time not reported)

Breastmilk ( 6 days after delivery); serum sample IgG, IgM (at 2 hours of age and 15 days of age); nasopharyngeal swab (5 tests from 2 hours to 16 days of age)

IgG, IgM negative; nasopharyngeal swab positive

Negative

Negative

Negative

$\operatorname{lgG} 140.32 \mathrm{AU} / \mathrm{mL}$, $\operatorname{lgM} 45.83 \mathrm{AU} / \mathrm{mL}$ ( 2 hours of age); IgG $69.94 \mathrm{AU} / \mathrm{mL}$, IgM $11.75 \mathrm{AU} / \mathrm{mL}$ (15 days of age). All RT-PCR tests results were negative

$\begin{array}{llll}{\text { Khan et } \mathrm{l}^{19}}^{19} & \text { China } & \text { Vaginal delivery } & 3 \\ \text { Lee et } \mathrm{al}^{20} & \text { Korea } & \text { Cesarean delivery } & 1 \\ & & \\ \text { Lei et al } & & \\ & \text { China } & \begin{array}{l}\text { Vaginal delivery } \\ (1), \text { cesarean de- }\end{array} & 4 \\ & & \begin{array}{l}\text { livery (3) } \\ \end{array}\end{array}$

Nasopharyngeal swab (time of collection not reported)

Negative

Negative blood (at delivery); two consecutive neonatal nasopharyngeal swab (time of collection not reported)

(1), cesarean de-

Vaginal secretion (time of collection not reported); amniotic fluid (at the time of delivery); cord blood (at the time of delivery); breastmilk (time of collection not reported); neonatal nasal and throat swab (time of collection not reported)

\begin{tabular}{|c|c|c|c|c|}
\hline Li et $\mathrm{al}^{6}(2020)$ & China & Cesarean delivery & 1 & $\begin{array}{l}\text { Neonatal throat swab ( } 3 \text { days after } \\
\text { birth) }\end{array}$ \\
\hline Li et $\mathrm{al}^{22}(2020)$ & China & Cesarean delivery & 1 & $\begin{array}{l}\text { Amniotic fluid, cord blood, pla- } \\
\text { centa, and breastmilk (on the de- } \\
\text { livery day); infant's oropharyngeal } \\
\text { swab, blood, feces, and urine } \\
\text { samples (seven different times at } \\
\text { day } 1 \text { and day } 2 \text { after birth) }\end{array}$ \\
\hline Liu et $\mathrm{al}^{23}(2020)$ & China & Cesarean delivery & 9 & Not reported \\
\hline Liu et $\mathrm{al}^{24}$ (2020) & China & $\begin{array}{l}\text { Vaginal delivery } \\
(1) \text {, cesarean de- } \\
\text { livery }(10)\end{array}$ & 11 & Not reported \\
\hline González et al ${ }^{25}$ & Spain & Cesarean delivery & 1 & Not reported \\
\hline Wang et $\mathrm{al}^{26}$ & China & Cesarean delivery & 1 & $\begin{array}{l}\text { Amniotic fluid (during delivery); } \\
\text { placenta (during delivery); cord } \\
\text { blood (during delivery); gastric } \\
\text { juice (during delivery); neonatal }\end{array}$ \\
\hline
\end{tabular}

Positive (neonatal throat swab)

Negative

Negative
Negative
Negative
Negative


Table 1 (Continued)

\begin{tabular}{|c|c|c|c|c|c|}
\hline Study (year) & Country & Delivery mode & $\begin{array}{l}\text { Number of } \\
\text { neonates } \\
\text { tested }\end{array}$ & $\begin{array}{l}\text { Samples (time of sample } \\
\text { collection) } \\
\text { throat swab (during delivery, } \\
\text { day } 3,7 \text {, and } 9 \text { after cesarean } \\
\text { delivery); neonatal stool samples } \\
\text { (day } 3 \text { after cesarean delivery) }\end{array}$ & $\begin{array}{l}\text { Sample } \\
\text { test } \\
\text { results }\end{array}$ \\
\hline Xiong et $\mathrm{al}^{27}$ & China & Vaginal delivery & 1 & $\begin{array}{l}\text { Amniotic fluid, neonatal throat } \\
\text { swab, and rectal swab (time of } \\
\text { collection not reported); neonatal } \\
\text { IgG and IgM antibodies (time of } \\
\text { collection not reported) }\end{array}$ & Negative \\
\hline Yao et $\mathrm{al}^{28}$ & China & Cesarean delivery & 1 & $\begin{array}{l}\text { Neonatal blood sample (after } \\
\text { delivery, day } 1 \text { after birth); neo- } \\
\text { natal nasal and throat swab (after } \\
\text { delivery, day } 1 \text { and } 9 \text { after birth); } \\
\text { anal swab (day } 9 \text { after birth) }\end{array}$ & Negative \\
\hline Yu et $\mathrm{al}^{7}(2020)$ & China & Cesarean delivery & 9 & $\begin{array}{l}\text { Neonatal throat swab (at } 36 \text { hours } \\
\text { after birth) }\end{array}$ & $\begin{array}{l}\text { Negative }(8) \text {, posi- } \\
\text { tive }(1)\end{array}$ \\
\hline Zeng et $\mathrm{al}^{8}$ & China & Cesarean delivery & 6 & $\begin{array}{l}\text { Neonatal throat swab and blood } \\
\text { sample (at birth); serum sample } \\
\text { lgG, IgM (at birth) }\end{array}$ & $\begin{array}{l}\text { Two had IgG and } \\
\text { IgM higher than } \\
\text { normal; three had } \\
\text { elevated IgG but } \\
\text { normal IgM levels. } \\
\text { All RT-PCR test } \\
\text { results were } \\
\text { negative. }\end{array}$ \\
\hline Zhang et $\mathrm{al}^{29}$ & China & Cesarean delivery & 10 & Neonatal throat swab (after birth) & Negative \\
\hline Zhou et al ${ }^{30}$ & China & Cesarean delivery & 1 & $\begin{array}{l}\text { Neonatal blood sample and throat } \\
\text { swab (on the day of birth, four and } \\
\text { seven days after birth) }\end{array}$ & Negative \\
\hline Zhu et $\mathrm{al}^{31}$ & China & $\begin{array}{l}\text { Vaginal delivery } \\
(2) \text {, cesarean de- } \\
\text { livery }(8)\end{array}$ & 10 & $\begin{array}{l}\text { Neonatal throat swab (day } 1-9 \\
\text { after birth) }\end{array}$ & $\begin{array}{l}\text { Negative (9), no } \\
\text { data (1) }\end{array}$ \\
\hline Zhuang et $\mathrm{al}^{32}$ & China & Cesarean delivery & 1 & $\begin{array}{l}\text { Breastmilk (day } 5 \text { after cesarean } \\
\text { delivery); neonatal throat swab } \\
\text { (day } 5 \text { after cesarean delivery) }\end{array}$ & Negative \\
\hline
\end{tabular}

Abbreviations: IgG, immunoglobulin G; IgM, immunoglobulin M.

Note: Unless specified otherwise, all tests were real-time polymerase chain reaction.

pregnancy can lead to fetal infection by intrauterine vertical transmission. Although evidence of neonatal infection has been reported, no positive RT-PCR results of the tests of amniotic fluid, placenta, cord blood, vaginal secretions, or breast milk have been reported. Thus, whether these neonates are infected during delivery or after birth is a concern.

The latest research suggests that angiotensin-converting enzyme 2 (ACE2) is the SARS-CoV-2 receptor required for cell entry, but the low level of ACE2 expression in cells at the maternal-fetal interface suggest that there are no susceptible cell subsets in these tissues. ${ }^{13}$ Moreover, pathological analysis suggests that there are no morphological changes related to the infection in placenta tissues. ${ }^{14}$ Therefore, these evidences do not support the possibility of intrauterine vertical transmission.

We noted that currently available data included only expectant mothers infected in their third trimester and due to the uncertainty of the impact of COVID-19 on maternal-fetal and neonatal outcomes, most babies were delivered by cesarean delivery as soon as possible after admission to minimize the risk. However, patients diagnosed in their first and second trimesters were still pregnant when these studies were published. The risk of adverse perinatal outcomes and vertical transmission is unclear, and this issue remains to be clarified by longer follow-up. Compared with the third trimester, maternal virus infection in the first or second trimesters of pregnancy may have different effects. For example, rubella virus infection before 12 weeks of pregnancy causes congenital rubella syndrome in $90 \%$ of cases, whereas the incidence is $50 \%$ in cases of infection at 13 to 14 weeks of pregnancy and $25 \%$ at the end of the second trimester; infection at the third trimester has little influence on the fetus. ${ }^{15}$

In terms of breastfeeding, although no positive RT-PCR results have been reported in tests of breast milk, this finding is limited by relatively small sample sizes and short followup time. Expert consensus ${ }^{16}$ suggests that infants should not be breastfed by mothers with confirmed or suspected SARS$\mathrm{CoV}-2$ infection. Indeed, breastfeeding may not be safe until COVID-19 is ruled out or until both mother and neonate clear 

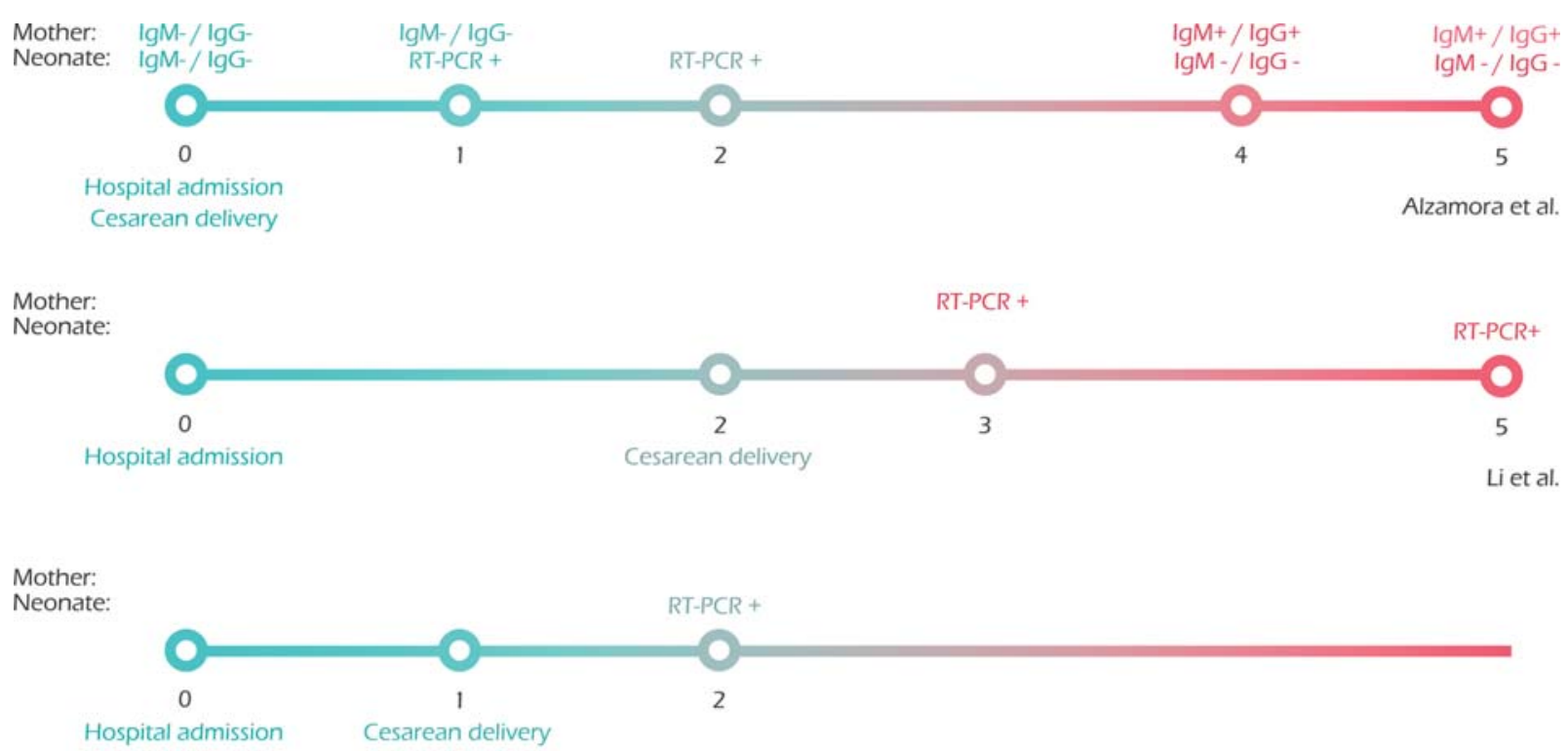

Fig. 2 Timelines illustrating the evolution of laboratory tests from the three cases with neonatal infection confirmed by real-time polymerase chain reaction.

the virus. Further analyses are needed to guide clinical practice in this setting.

As there is no evidence to support the possibility of intrauterine vertical transmission, the timing of delivery should not be based solely on the condition that a pregnant patient is infected but should be individualized in each case; that is, obstetricians may consider maternal and fetal wellbeing, gestational age, and other concomitant conditions to determine the time of delivery. ${ }^{17}$ In terms of delivery mode, there is a lack of convincing evidence that cesarean delivery is safer. The mode of delivery should be based on routine obstetrical indications, allowing vaginal delivery when possible and reserving cesarean delivery for when obstetrically necessary. ${ }^{16}$

\section{Conclusion}

The currently available evidence does not support the possibility of intrauterine vertical transmission of SARS-CoV-2 infection during the third trimester of pregnancy. No positive RT-PCR results of tests of amniotic fluid, placenta, cord blood, or breast milk have been reported. For pregnant women infected during their first and second trimesters, further studies focusing on long-term outcomes are needed. We recommend additional RT-PCR testing of amniotic fluid, placenta, and cord blood to confirm these findings.

\section{Conflict of Interest}

None declared.

\section{ReferencesReferences}

1 Zhu N, Zhang D, Wang W, et al; China Novel Coronavirus Investigating and Research Team. A novel coronavirus from patients with pneumonia in China, 2019. N Engl J Med 2020; 382(08):727-733
2 Huang C, Wang Y, Li X, et al. Clinical features of patients infected with 2019 novel coronavirus in Wuhan, China. Lancet 2020;395 (10223):497-506

3 Lv M, Luo X, Estill J, et al; On Behalf Of The Covid-Evidence And Recommendations Working Group. Coronavirus disease (COVID19): a scoping review. Euro Surveill 2020;25(15):25

4 Chen H, Guo J, Wang C, et al. Clinical characteristics and intrauterine vertical transmission potential of COVID-19 infection in nine pregnant women: a retrospective review of medical records. Lancet 2020;395(10226):809-815

5 Alzamora MC, Paredes T, Caceres D, Webb CM, Valdez LM, La Rosa M. Severe COVID-19 during pregnancy and possible vertical transmission. Am J Perinatol 2020;37(08):861-865

6 Li M, Xu M, Zhan W, Han T, Zhang G, Lu Y. Report of the first cases of mother and infant infections with 2019 novel coronavirus in Xinyang City Henan Province. Chin J Infect Dis 2020. Doi: 10.3760/ cma.j.issn.1000-6680.2020.0007

7 Yu N, Fang Z, Wu J. Novel coronavirus pnuemonia in pregnancy: perinatal outcomes. Progress Obstet Gynecol 2020. Doi: 10.1002/ uog.22006

8 Zeng H, Xu C, Fan J, et al. Antibodies in infants born to mothers with COVID-19 pneumonia. JAMA2020;323(18):1848-1849

9 Dong L, Tian J, He S, et al. Possible vertical transmission of SARSCoV-2 from an infected mother to her newborn. JAMA2020

10 Arora N, Sadovsky Y, Dermody TS, Coyne CB. Microbial vertical transmission during human pregnancy. Cell Host Microbe 2017; 21(05):561-567

11 Silasi M, Cardenas I, Kwon JY, Racicot K, Aldo P, Mor G. Viral infections during pregnancy. Am J Reprod Immunol 2015;73(03): 199-213

12 Shih YF, Liu CJ. Mother-to-infant transmission of hepatitis B virus: challenges and perspectives. Hepatol Int 2017;11(06):481-484

13 Zheng Q, Duan T, Jin L. Single-cell RNA expression profiling of ACE2 and AXL in the human maternal-fetal interface. Reprod Dev Med 2020. Available at: http://www.repdevmed.org/article.asp? issn $=2096-2924$; year $=2020$; volume $=4$; issue $=1$; spage $=7$; epage=10;aulast=Zheng. Accessed April 30, 2020

14 Chen S, Huang B, Luo D. Pregnant women with new coronavirus infection: a clinical characteristics and placental pathological analysis of three cases. Chin J Patho 2020. Doi: 10.3760/cma.j. cn112151-20200225-00138 
15 De Santis M, Cavaliere AF, Straface G, Caruso A. ubella infection in pregnancy. Reprod Toxicol 2006;21(04):390-398

16 Chen D, Yang H, Cao Y, et al. Expert consensus for managing pregnant women and neonates born to mothers with suspected or confirmed novel coronavirus (COVID-19) infection. Int J Gynaecol Obstet 2020;149(02):130-136

17 Qi H, Luo X, Zheng Y, et al. Safe delivery for COVID-19 infected pregnancies. BJOG 2020. Doi: 10.1111/1471-0528.16231

18 Chen X, Li Y, Wang J, Cai H, Cao H, Sheng J. Pregnant women complicated with corona virus disease 2019 (COVID-19): a clinical analysis of 3 cases. J Zhejiang Univ 2020. DOI: 10.3785/j. issn.1008-9292.2020.03.08

19 Khan S, Peng L, Siddique R, et al. Impact of COVID-19 infection on pregnancy outcomes and the risk of maternal-to-neonatal intrapartum transmission of COVID-19 during natural birth. Infect Cont Hosp Ep 2020. DOI: 10.1017/ice.2020.84

20 Lee DH, Lee J, Kim E, Woo K, Park HY, An J. Emergency cesarean section on severe acute respiratory syndrome coronavirus 2 (SARS- CoV-2) confirmed patient. Korean J Anesthesiol 2020. DOI: $10.4097 / \mathrm{kja} .20116$

21 Lei D, Wang C, Li C, et al. Clinical characteristics of COVID-19 in pregnancy: analysis of nine cases. Chin J Perinat Med 2020. DOI: 10.3760/cma.j.cn113903-20200216-00117

22 Li Y, Zhao R, Zheng S, et al. Lack of vertical transmission of severe acute respiratory syndrome coronavirus 2, China. Emerg Infect Dis 2020. DOI: $10.3201 /$ eid2606.200287

23 Liu Y, Chen H, Tang K, Guo Y. Clinical manifestations and outcome of SARS-CoV-2 infection during pregnancy. J Infect 2020. DOI: 10.1016/j.jinf.2020.02.028

24 Liu D, Li L, Wu X, et al. Pregnancy and Perinatal Outcomes of Women With Coronavirus Disease (COVID-19) Pneumonia: A
Preliminary Analysis. Am J Roentgenol 2020. DOI: 10.2214/ AJR.20.23072

25 González RD, Ocampo PJ, González BL, Santana-Cabrera L. Pregnancy and perinatal outcome of a woman with COVID-19 infection. Revista Clínica Española 2020. DOI: 10.1016/j.rce.2020. 04.006

26 Wang X, Zhou Z, Zhang J, Zhu F, Tang Y, Shen X. A case of 2019 Novel Coronavirus in a pregnant woman with preterm delivery. Clin Infect Dis 2020. DOI: $10.1093 /$ cid/ciaa200

27 Xiong X, Wei H, Zhang Z, et al. Vaginal Delivery Report of a Healthy Neonate Born to a Convalescent Mother with COVID19. J Med Virol 2020. DOI: $10.1002 /$ jmv.25857

28 Yao L, Wang J, Zhao J, Cui J, Hu Z. Asymptomatic COVID-19 infection in pregnant woman in the third trimester: a case report. Chin J Perinat Med 2020. DOI: 10.3760/cma.j.cn113903-20200 221-00143

29 Zhang L, Jiang Y, Wei M, et al. Analysis of the pregnancy outcomes in pregnant women with COVID-19 in Hubei Province. Chin J Obstet Gynecol 2020. DOI:10.3760/cma.j.cn112141-2020021800111

30 Zhou R, Chen Y, Lin C, et al. Asymptomatic COVID-19 in pregnant woman with typical chest CT manifestation: a case report. Chin J Perinat Med 2020. DOI: 10.3760/cma.j.cn113903-2020022000134

31 Zhu H, Wang L, Fang C, et al. Clinical analysis of 10 neonates born to mothers with 2019-nCoV pneumonia. Transl Pediatr 2020;9 (1):51-60

32 Zhuang S, Guo J, Cao Y, et al. Perinatal novel coronavirus infection: a case report. Chin J Perinat Med 2020. DOI: 10.3760/cma.j. issn.1007-9408.2020.02.003 